\title{
Study of Agrometeorological Indices as Affected by Different Duration Rice Varieties and Crop Establishment Methods
}

\author{
D. N. Jagtap*, M. W. Sutar, U. V. Mahadkar, S. A. Chavan, S. S. Pinjari and M. S. Jadhav
}

Dept. of Agronomy, College of Agriculture, Dapoli, Dr. Balasaheb Sawant Konkan Krishi Vidyapeeth, Dapoli, Maharashtra (415 712), India

\section{Corresponding Author}

D. N. Jagtap

e-mail: mauli296@gmail.com

\author{
Article History \\ Article ID: AR1894 \\ Received in $20^{\text {th }}$ August, 2018 \\ Received in revised form $19^{\text {th }}$ September, 2018 \\ Accepted in final form $02^{\text {nd }}$ November, 2018
}

\begin{abstract}
A field experiment was conducted on Agronomy farm, College of Agriculture, Dapoli, Maharashtra, India during kharif(June) 2015 and 2016 to study of agrometeorological indices as affected bydifferent duration rice varieties and crop establishment methods. The experiment was laid out according to split plot design with three replications. Twenty four treatment combinations comprised of four main plot treatments: Drilling, Early transplanting (15 days after sowing), Transplanting as per recommendation (21 days after sowing) and Transplanting with Thomba method (under insufficient rain water for puddling, this method usually preferred. In this case transplating has been completed without puddling. With the help ofpointed bamboo stick holes has been made and seedlings inserted into that holes) and six subplot treatments Karjat-184, Palghar-1, Karjat-2, Sahyadri-2, Karjat-3 and Karjat-7. To obtain higher yield from kharif rice, crop should to be established by transplanting method with variety Sahyadri-2 followed by Karjat-7. However, early transplanting and Thomba methods are the alternatives to conventional transplanting method. Because with Thomba method we can complete transplanting of rice even if insufficient rainwater is there for puddling and get the better yield comparatively. The highest GDD, Hydrothermal units and Helio-thermal units required by Karjat-2 variety, while higher Heat use efficiency and Helio-thermal use efficiency recorded by Sahyadri-2 variety.
\end{abstract}

Keywords: Rice, Crop establishment methods, varieties, agrometeorological indices

\section{Introduction}

Rice (Oryza sativa L.) is one of the most important staple food grain crop of the World, which constitute the principal food for $60 \%$ of the World's population and $2 / 3^{\text {rd }}$ of Indian population. India is the World's second largest rice producer and consumer next to China. Total area under rice in India is $43.39 \mathrm{mha}$ with annual production of $104.32 \mathrm{mt}$, though production is large, the per hectare yield is very poor i.e. $2.40 \mathrm{t} \mathrm{ha}^{-1}$, as compared to other rice growing countries like Egypt (6.45 t ha-1), USA (5.63 $\left.\mathrm{t} \mathrm{ha}^{-1}\right)$, Japan (4.73 $\left.\mathrm{t} \mathrm{ha}^{-1}\right)$ and China (4.74 $\left.\mathrm{t} \mathrm{ha}^{-1}\right)$. In Maharashtra, rice is cultivated over an area of 15.3 lakh ha and an annual production of about 26.3 lakh $\mathrm{t}$ with a productivity of $1714 \mathrm{~kg} \mathrm{ha}^{-1}$ (Anonymous, 2016). However, variations in rice productivity are governed by seasonal and spatial differences in climatic factors and their degree of influence at a particular phenophase of rice crop by Jagtap et al. (2017). The yield variation is also due to aberration in weather like late onset of monsoon, heavy continuous rains, intermittent dry spell and heavy rains at the time of harvesting, etc.
The productivity of rice is low due to delay in nursery sowing and late transplanting by Jagtap et al. (2011); Ghasal et al. (2014). The secret of boosting its yields mainly lies in timely transplanting and proper fertilizer scheduling of the crop. At the time of transplanting availability of labour is the main constraint in the region, Anonymous (1997); Jagtap and Mahadkar (2017). Under the scarcity of labour farmers give priority for drilling of rice. Therefore, the establishment of crop is very slow in drilling method as a result; the yield of crop is reduced to greater extent, Jagtap et al. (2016). In other parts of the country, mostly rice is grown by drilling the seeds. However, in Konkan region it is usually grown by raising nurseries and transplanting seedlings in the field, Jagtap and Mahadkar (2017). Though transplanted crop gives higher yield over the direct sown crop, it is realized that, transplanted crop requires more labour for uprooting and transplanting of seedlings which are extremely time consuming and not feasible with the rapid industrialization in the region due to shortage of labour and increase in wage rates. The scarcity of labour is being felt for quite some time in the rural areas, which leaves no option other than direct 
sowing of rice which is quicker and may become economically viable method, Jagtap and Mahadkar (2017). The systematic study on the performance of rice grown by direct seed sowing in comparison with transplanting, early transplanting and thomba method in the region.

With the above background in view, an attempt has been made to study of agrometeorological indices on rice as affected by different crop establishment methods and varieties.

\section{Materials and Methods}

A field experiment was conducted on Agronomy farm $\left(17^{0} .45^{\prime}\right.$ North latitude and $73^{\circ} .10^{\prime}$ East longitude), College of Agriculture, Dapoli, Maharashtra, Indiaduring kharif, 2015 and 2016 to study of agrometeorological indices on rice as affected by different crop establishment methods and varieties. The experiment was laid out according to split plot design with three replications. Twenty four treatment combinations comprised of four main plot treatments Drilling $\left(M_{1}\right)$, Early transplanting (15 days after sowing) $\left(\mathrm{M}_{2}\right)$, Transplanting as per recommendation (21 days after sowing) $\left(M_{3}\right)$ and Transplanting with Thomba method (under insufficient rain water for puddling, this method usually preferred. In this case without puddling, transplating completed. With the help ofpointed bamboo stick holes has been made and seedlings inserted into that holes) $\left(\mathrm{M}_{4}\right)$ and six subplot treatments Karjat-184 $\left(\mathrm{V}_{1}\right)$, Palghar-1 $\left(\mathrm{V}_{2}\right)$, Karjat-2 $\left(\mathrm{V}_{3}\right)$, Sahyadri-2 $\left(\mathrm{V}_{4}\right)$, Karjat-3 $\left(\mathrm{V}_{5}\right)$ and Karjat-7 $\left(\mathrm{V}_{6}\right)$.Dibbling of seeds was done on commencement of mansoon for dibbled rice treatment and also for nursery for other treatments. Fifteen days and Twenty one days old nursery seedling was transplanted by following a spacing of $20 \times 15 \mathrm{~cm}^{2}$ as per treatments. In RDF (100:50:50 NPK kg ha-1), 40\% $\mathrm{N}$ and full dose of $\mathrm{P}$ and $\mathrm{K}$ were applied at the time of transplanting. Remaining $40 \% \mathrm{~N}$ was applied at maximum tillering (30 DAT) and $20 \%$ at panicle initiation stage (65 DAT) as per treatments. Urea, Single super phosphate and muriate of potash are the sources of fertilizers for RDF. Other cultural practices and plant protection measures were followed as per the recommended package of practices. The periodical observations on growth, micrometeorological parameters and yield contributing characters were recorded to assess the treatment effects.

\subsection{Growing degree days (GDD)}

Temperature is a major environmental factor that determines the rate of plant development. The temperature requirement and range of optimum temperature varied with species and genotype. The thermal response of genotype can be quantified by using the heat unit or thermal time concept. There is high probability of successfully predicting the development of black gram by heat unit.

Thermal time or growing degree days were calculated according to the equation. (Mali et al., 2000).

$n$

G.D.D. $=\Sigma[(T \max .+T \min ) / 2-.T b]$

$\mathrm{i}=1$
Where, G.D.D.=Growing degree days, $\mathrm{Tmax} .=$ Daily maximum temperature of day $i\left({ }^{\circ} \mathrm{C}\right)$, Tmin.=Daily minimum temperature of day $\mathrm{i}\left({ }^{\circ} \mathrm{C}\right)$ and $\mathrm{Tb}=$ Base temperature.

In present study, the base temperature of rice was taken as $10^{\circ} \mathrm{C}$.

\subsection{Hydro thermal units}

The Hydro thermal units were calculated by multiplying GDD with average humidity at critical stages of crop.

Hydro thermal units=GDD $\times$ Average humidity

\subsection{Helio-thermal units}

The Helio-thermal units was calculated by multiplying GDD with mean BSS at critical stages of crop.

Helio thermal units $=$ GDD $\times$ mean BSS

Helio-thermal units (HTU) and photo thermal units (PTU) were determined by theequation proposed by Singh et al. (1990) and Nuttonson (1948), respectively.

\section{Results and Discussion}

\subsection{Yield}

Grain yield $\left(\mathrm{kg} \mathrm{ha}^{-1}\right)$ and straw yield $\left(\mathrm{kg} \mathrm{ha}^{-1}\right)$ as influenced by different establishment methods are given in Table 1. Establishment methods and varieties showed significant variation on grain yield and straw yield. The establishment method Normal transplanting as per recommendation was significantly superior over rest of all the treatments. Early transplanting is significantly superior over Thomba and Drilling while least grain yield and straw yield $\left(\mathrm{kg} \mathrm{ha}^{-1}\right)$ was recorded in Drilling method. These results are similar to those reported by Anbumani et al. (2004), Awan et al. (2007), Aslam et al. (2008), Jayadeva and Prabhakar Shetty (2008), Singh et al. (2008), Chandrapala (2009), Hugar et al. (2009), Jagtap et al. (2011), Brar et al. (2012), Javaid et al. (2012), Jagtap et al. (2012), Raj et al. (2012), Jagtap et al. (2013), Rajiv (2013), Ghasal et al. (2014), Masud et al. (2014), Jagtap et al. (2016), Pawar et al. (2017) and Rajiv et al. (2018).

The varieties also showed significant variation in grain yield and. Significantly higher grain yield (4675.14 $\left.\mathrm{kg} \mathrm{ha}^{-1}\right)$ was recorded in variety Sahyadri-2 over Karjat-7 $(4180.37 \mathrm{~kg}$ $\left.\mathrm{ha}^{-1}\right)$, Karjat-2 (4174.00 kg ha-1), Karjat-3 (3690.08 kg ha-1), Palghar-1 (3674.62 kg ha-1) and Karjat-184 (3332.95 kg ha-1). The maximum straw yield (5610.17 $\mathrm{kg} \mathrm{ha}^{-1}$ ) was recorded in variety Sahyadri-2 which was significantly higher than Karjat-7 (5016.45 kg ha-1) Karjat-2 (5008.80 kg ha-1), Karjat-3 (4428.09 $\mathrm{kg} \mathrm{ha}^{-1}$ ), Palghar-1 (4409.54 kg ha ${ }^{-1}$ ) and Karjat-184 (3999.54 kg $\left.\mathrm{ha}^{-1}\right)$. These results are in conformity with the results reported by Mahajan and Bharaj(2008), Rajiv (2013), Singh (2013), Sharif et al. (2014), Hardev et al. (2014), Yadav and Meena (2014), Ghasal et al. (2014), Masud et al. (2014), Jagtap et al. (2017) and Singh et al. (2017).

\subsection{Phenological studies}

The sequential study of development stages (i.e. crop growth 
Table 1: Grain and straw yield ( $\mathrm{kg} \mathrm{ha}^{-1}$ ) of rice, Heat use efficiency and Helio-thermal use efficiency influenced by different treatments

\begin{tabular}{|c|c|c|c|c|}
\hline Treatments & GY & SY & HUESY & HUTESY \\
\hline \multicolumn{5}{|c|}{ Methods of establishment } \\
\hline $\mathrm{M}_{1}$ : Drilling & 3509.52 & 4218.52 & 1.81 & 0.56 \\
\hline $\begin{array}{l}\mathrm{M}_{2} \text { : Early trans- } \\
\text { planting ( } 15 \text { days } \\
\text { after sowing) }\end{array}$ & 4143.53 & 4965.39 & 2.14 & 0.66 \\
\hline $\begin{array}{l}\mathrm{M}_{3}: \text { Transplanting } \\
\text { as per recom- } \\
\text { mendation }\end{array}$ & 4426.19 & 5311.42 & 2.29 & 0.71 \\
\hline $\begin{array}{l}\mathrm{M}_{4} \text { : Transplant- } \\
\text { ing with Thomba } \\
\text { method }\end{array}$ & 3738.87 & 4486.39 & 1.93 & 0.60 \\
\hline SEm \pm & 44.78 & 73.31 & -- & -- \\
\hline$C D(p=0.05)$ & 154.95 & 253.69 & -- & -- \\
\hline \multicolumn{5}{|l|}{ Varieties } \\
\hline $\mathrm{V}_{1}:$ Karjat-184 & 3332.95 & 3999.54 & 1.98 & 0.68 \\
\hline $\mathrm{V}_{2}:$ Palghar-1 & 3674.62 & 4409.54 & 1.96 & 0.63 \\
\hline $\mathrm{V}_{3}:$ Karjat-2 & 4174.00 & 5008.80 & 2.25 & 0.72 \\
\hline $\mathrm{V}_{4}$ : Sahyadri-2 & 4675.14 & 5610.17 & 2.47 & 0.79 \\
\hline $\mathrm{V}_{5}:$ Karjat-3 & 3690.08 & 4428.09 & 1.83 & 0.56 \\
\hline $\mathrm{V}_{6}:$ Karjat-7 & 4180.37 & 5016.45 & 1.84 & 0.49 \\
\hline SEm \pm & 75.57 & 95.59 & -- & -- \\
\hline $\mathrm{CD}(p=0.05)$ & 216.01 & 273.22 & -- & -- \\
\hline \multicolumn{5}{|l|}{ Interaction effect } \\
\hline SEm \pm & 22845.50 & 36550.18 & -- & -- \\
\hline $\mathrm{CD}(p=0.05)$ & N.S. & N.S. & -- & -- \\
\hline
\end{tabular}

GY: Grain yield $\left(\mathrm{kg} \mathrm{ha}^{-1}\right)$; SY: Straw yield $\left(\mathrm{kg} \mathrm{ha}^{-1}\right)$; HUESY: Heat use efficiency seed yield; HUTESY: Helio-thermal use efficiency seed yield

stages) of the crop is known as phenology. The duration (days) taken for commencement of different phonological events viz., Sowing to Germination $\left(P_{1}\right)$, Germination to Seeding stage $\left(P_{2}\right)$, Seeding stage to Tillering stage $\left(P_{3}\right)$, Tillering stage to Panicle Initiation $\left(\mathrm{P}_{4}\right)$, Panicle Initiation to Panicle Development and Flowering $\left(P_{5}\right)$, Panicle Development and Flowering to Grain Filling and Maturity Stage(P6) for differentvarieties of the rice crop is given in Table 2. It is clearly understood from the Table 2. that total days required from sowing to maturity ranged from 106 to 143 days. The duration of the crop was varied in different varieties is due to the duration as well as different weather condition prevailed in different phenophases of rice.

\subsection{Agro meteorological indices}

Rice crop grown in tropical and subtropical regions in which weather play major role in crop production. Among the climatic factors, temperature and humidity plays key role in determining duration of differentphenophases which affect the cropproductivity. Hence, knowledge of the exact duration of all the developmental phases and their association with yield determinants is essential for achieving high yield. Growing degree (GDD) days, Hydro thermal units (HTU) and Helio-thermal units (HTU) are good estimators of rice growth stages. Agro meteorological indices showed the temperature impact on the growth and yield of crop. The data on the agro meteorological indices are given in the Table 2.

\subsubsection{Growing degree days (degree days)}

The data given in the Table 2 showed that the number of growing degree days was accumulated during the each phenophase at the base temperature of $10.0^{\circ} \mathrm{C}$ and it was obtained $1933.8^{\circ} \mathrm{C}$ days as general mean of varieties. Highest GDD was recorded $\left(685^{\circ} \mathrm{C}\right.$ day) in seedling to tillering stage $\left(P_{3}\right)$ of Karjat-2 variety and lowest GDD recorded at sowing to emergence $\left(P_{1}\right)$ as the less number of days required for complete this phenophase in every variety. The data presented in Table 2 revealed that the total heat unit requirement of all the varieties during crop life cycle was $1680^{\circ} \mathrm{C}$ (Karjat-184), $1877^{\circ} \mathrm{C}$ (Sahyadri-2), $1855^{\circ} \mathrm{C}$ (Karjat-3), $1893^{\circ} \mathrm{C}$ (Karjat-7), $2021{ }^{\circ} \mathrm{C}$ (Palghar-1), 2277 (Karjat-2). It might be due to the different crop duration in these four varieties. These results are in conformity with the results reported by Chahal et al. (2007), Rajinder Pal et al. (2017) and Jagtap et al. (2018).

\subsubsection{Hydro thermal unit $\left({ }^{\circ} \mathrm{C}\right.$ day hours)}

Photo thermal unit is the agrometeorological indices that indicated how much quantity of heat energy is used by the plant during the day. It is calculated by multiplying the daily heat units or GDD with the length of day. The no. of photo thermal units to be accumulated by the crop during it life cycle at different phenophases are given in the Table 2. The photo thermal units were influenced by the number of days required for reaching to each phenophase or to complete life cycle.The data given in the Table 2 showed that number photothermal units was accumulated during the each phenophase at the base temperature of $10.0{ }^{\circ} \mathrm{C}$ was significantly influenced by different varieties. The data revealed that average hydrothermal units accumulated during different varieties were observed $171691{ }^{\circ} \mathrm{C}$ day hrs. whereas, the highest photo thermal units was recorded in Karjat-2 $\left(200302{ }^{\circ} \mathrm{C}\right.$ day hrs) followed by Palghar-1 $\left(179283^{\circ} \mathrm{C}\right.$ day hrs), Karjat-7 (168454 ${ }^{\circ} \mathrm{C}$ day hrs), Sahyadri-2 (167135 ${ }^{\circ} \mathrm{C}$ day hrs), Karjat-3 (165245 ${ }^{\circ} \mathrm{C}$ day hrs), Karjat-184 (149729 ${ }^{\circ} \mathrm{C}$ day hrs). However, within all crop growth stages the highest hydrothermal units were recorded at seedling to tillering stage $\left(\mathrm{P}_{3}\right)$. The lowest no. of hydrothermal units was accumulated from sowing to emergence stage $\left(P_{1}\right)$ in all the varieties. These results are in conformity with the results reported by Chahal et al. (2007), Rajinder Pal et al. (2017) and Jagtap et al. (2018). 
Table 2: Phenophase wise agrometeorological indices required as influenced by various varieties of rice during kharif, 2015 and 2016 (pooled)

\begin{tabular}{|c|c|c|c|c|c|c|c|}
\hline \multirow[t]{2}{*}{ Varieties } & \multicolumn{7}{|c|}{ Phenophases } \\
\hline & $\begin{array}{c}\text { Germination } \\
\left(P_{1}\right)\end{array}$ & $\begin{array}{l}\text { Seeding } \\
\text { stage }\left(P_{2}\right)\end{array}$ & $\begin{array}{l}\text { Tillering } \\
\text { stage }\left(P_{3}\right)\end{array}$ & $\begin{array}{l}\text { Panicle Ini- } \\
\text { tiation }\left(\mathrm{P}_{4}\right)\end{array}$ & $\begin{array}{l}\text { Panicle development } \\
\text { and flowering }\left(\mathrm{P}_{5}\right)\end{array}$ & $\begin{array}{l}\text { Grain filling and } \\
\text { maturity stage }\left(\mathrm{P}_{6}\right)\end{array}$ & Total \\
\hline \multicolumn{8}{|c|}{ Days required to phenophases } \\
\hline Karjat-184 & 5 & 15 & 36 & 4 & 17 & 29 & 106 \\
\hline Sahyadri-2 & 5 & 16 & 38 & 6 & 20 & 30 & 115 \\
\hline Karjat-3 & 5 & 14 & 37 & 5 & 19 & 29 & 109 \\
\hline Karjat-7 & 5 & 23 & 28 & 14 & 25 & 25 & 120 \\
\hline Palghar-1 & 5 & 18 & 39 & 10 & 23 & 30 & 125 \\
\hline Karjat-2 & 5 & 24 & 43 & 15 & 26 & 30 & 143 \\
\hline \multicolumn{8}{|c|}{ Growing degree days (degree days) } \\
\hline Karjat-184 & 87 & 239 & 585 & 63 & 269 & 437 & 1680 \\
\hline Sahyadri-2 & 87 & 255 & 617 & 96 & 322 & 501 & 1877 \\
\hline Karjat-3 & 87 & 255 & 617 & 96 & 322 & 479 & 1855 \\
\hline Karjat-7 & 87 & 255 & 617 & 104 & 322 & 509 & 1893 \\
\hline Palghar-1 & 87 & 288 & 630 & 165 & 366 & 485 & 2021 \\
\hline Karjat-2 & 87 & 390 & 685 & 230 & 396 & 488 & 2277 \\
\hline \multicolumn{8}{|c|}{ Hydro thermal unit ( ${ }^{\circ} \mathrm{C}$ day hours) } \\
\hline Karjat-184 & 7453 & 21975 & 52095 & 5895 & 23891 & 38420 & 149729 \\
\hline Sahyadri-2 & 7453 & 23380 & 55149 & 8700 & 28528 & 43925 & 167135 \\
\hline Karjat-3 & 7453 & 23380 & 55149 & 8700 & 28528 & 42035 & 165245 \\
\hline Karjat-7 & 7453 & 23380 & 55149 & 9424 & 28480 & 44567 & 168454 \\
\hline Palghar-1 & 7453 & 26289 & 56478 & 14635 & 31761 & 42665 & 179283 \\
\hline Karjat-2 & 7453 & 35300 & 61283 & 20551 & 34766 & 40950 & 200302 \\
\hline \multicolumn{8}{|c|}{ Helio thermal unit ( ${ }^{\circ} \mathrm{C}$ day hours) } \\
\hline Karjat-184 & 358 & 434 & 1466 & 110 & 865 & 1664 & 4899 \\
\hline Sahyadri-2 & 358 & 437 & 1535 & 131 & 1226 & 2128 & 5813 \\
\hline Karjat-3 & 358 & 437 & 1535 & 131 & 1226 & 2076 & 5761 \\
\hline Karjat-7 & 358 & 437 & 1535 & 147 & 1235 & 2190 & 5902 \\
\hline Palghar-1 & 358 & 509 & 1515 & 561 & 1639 & 2065 & 6647 \\
\hline Karjat-2 & 358 & 880 & 1635 & 870 & 1646 & 3068 & 8457 \\
\hline
\end{tabular}

\subsubsection{Helio thermal unit}

The variation in mean daily temperature and bright sunshine hour among duration of six varieties resulted in varied accumulated helio-thermal units at different phenophases and life cycle of rice crop. The total helio-thermal units were observed during different phenophases of different varieties ranged from 110 to $3068{ }^{\circ} \mathrm{C}$ day hour. The data presented in Table 2 showed that total HTU required during total crop growth period was highest in variety Karjat- $28457^{\circ} \mathrm{C}$ day hour as compare to remaining other varieties. It might be due to different growth period.These results are in conformity with the results reported by Chahal et al. (2007), Rajinder Pal et al. (2017) and Jagtap et al. (2018).

\subsubsection{Heat use efficiency and helio-thermal use efficiency}

At maturity, heat use efficiency for grain was higher (2.29) for crop established by transplanting as per recommendation methodas compared to rest of treatment. Among varieties, Sahyadri-2 had significantly higher heat use efficiency (2.47) followed by Karjat-2 (2.25), Karjat-184 (1.98), Palghar-1 (1.96), Karjat-7 (1.84) and Karjat-3 (1.83) for grain production.

Helio-thermal use efficiency for grain was found maximum 0.71 for Transplanting as per recommendation method. In case of varieties, Sahyadri-2 had highest helio-thermal 
use efficiency 0.79 for grain production. The minimum heliothermal use efficiency was found in Karjat-7 (0.49) for grain production. As the temperature was optimum throughout growing period crop utilized heat more efficiently and increased biological activity that confirm higher yield. These results are in conformity with the results reported by Chahal et al. (2007), Rajinder Pal et al. (2017) and Jagtap et al. (2018).

\section{Conclusion}

For growing kharif rice, crop need to be established by transplanting method with variety Sahyadri-2 followed by Karjat-7 to obtain higher yield followed by early transplanting and Thomba methods. Because with Thomba method we can complete transplanting of rice even if insufficient rainwater is there for puddling and get the better yield comparatively. The highest GDD, Hydrothermal units and Helio-thermal units required by Karjat- 2 variety, while higher Heat use efficiency and Helio-thermal use efficiency recorded by Sahyadri-2 variety.

\section{References}

Anonymous, 1997. Research highlights (1992-97). Konkan Krishi Vidyapeeth, Dapoli, Maharashtra, India.

Anbumani, S., Chandrasekharan, B., Kuppuswamy, G., 2004. Evaluation of establishment methods and NPK levels in rice and their impact on succeeding crops. Agricultural Science Digest 24(3) 190-193.

Awan, T.H., Ali, I., Safdar, M.E., Ashraf, M.M., Yaqub, M., 2007. Economic effect of different establishment techniques on rice, Oryza sativa production. Journal of Agricultural Research 45(1), 73-81.

Anonymous, 2016. Agricultural statistics at a Glance, 2016. Available from: https://eands.dacnet.nic.in/\#

Aslam, M., Hussain, S., Ramzan, M., Akhter, M., 2008. Effect of different stand establishment techniques on rice yield and its attributes. Journal of Animal and Plant Sciences 18(2-3), 80-82.

Brar, S.K., Mahal, S.S., Brar, A.S., Vashist, K.K., Sharma, N., Buttar, G.S., 2012. Transplanting time and seedling age affect water productivity, rice yield and quality in North-West India. Agricultural Water Management 115, 217-222.

Chahal, G.B.S., Sood, A., Jalota, S.K., Choudhury, B.U., Sharma, P.K., 2007. Yield, evapo-transpiration and water productivity of rice-wheat system in Punjab (India) as influenced by transplanting date of rice and weather parameters. Agricultural Water Management 88, 14-22.

Chandrapala, A.G., 2009. Productivity of rice-maize cropping system as influenced by crop establishment methods and nutrient management ( $S$ and $\mathrm{Zn}$ ).Ph.D thesis submitted to Achraya N.G. Ranga Agricultural University.

Ghasal, P.C.,Bir, D., Yadav, A.,Prakesh, V., Verma, R.K., 2014. Productivity and profitability of rice varieties under different methods of establishment. Annals of Agricultural Research, New series 35(3), 298-303.

Hardev, R., Singh, J.P., Bohra, J.S., Singh, K.R., Sutaliya, J.M., 2014. Effect of seedling age and plant spacing on growth, yield, nutrient uptake and economics of rice genotypes under system of rice intensification. Indian Journal of Agronomy 59(2)256-260.

Hugar, A.Y., Chandrappa, H., Jayadeva, H.M., Satish, A., Mallikarjun, G.B., 2009. Influence of different establishment methods on yield and economics of rice. Agriculture Science Digest 29(3), 202-205.

Jagtap, D.N., Mahadkar, U.V.,Chavan, L.S., 2011. Productivity and economics of rice influenced by different crop establishment methods and fertilizer sources. International Journal of Forestry \& Crop Improvement 2(2), 170-175.

Jagtap, D.N., Mahadkar, U.V., Chavan, L.S., Ch. Srinivasarao, 2012. Performance of rice (Oryza sativa L.) influenced by different crop establishment methods and fertilizer sources. Indian Journal of Dryland Agricultural Research \& Development 27(2), 55-58.

Jagtap, D.N., Mahadkar, U.V.,Chavan, L.S., 2013. Response of hybrid rice to different crop establishment methods and fertilizer sources. Bioinfolet 10(1 B), 327-332.

Jagtap, D.N., Mahadkar, U.V., Chavan, S.A., 2016. Response of rice varieties to establishment methods under konkan conditions. Indian Society of Coastal Agricultural Research 34(2), 85-87.

Jagtap, D.N., Mahadkar, U.V., Chavan, S.A., 2017. Response of rice varieties to different sowing windows under Konkan conditions. Agricultural Science Digest 37(1), 78-80.

Jagtap, D.N., Mahadkar, U.V., 2017. Rice establishment methods in Konkan, Maharashtra, 156.

Jagtap, D.N., Rajemahadik, V.A., Mahadkar, U.V., Chavan, S.A., 2018. Effect of different weather parameters on the growth and yield attributes and yield of rice (Oryza sativa L.). Journal of the Indian Society of Coastal Agricultural Research 36(1), 80-83.

Javaid, T., Awan, U., Baloch, M.S., Shah, I.H., Nadim, M.A., Khan, E.A., Khakwani, A.A., Abuzar, M.R., 2012. Effect of planting methods on the growth and yield of coarse rice.Journal of Animal and Plant Sciences 22(2), 358-362.

Jayadeva, H.M., Prabhakar Shetty, T.K., 2008. Influence of crop establishment techniques and sources of nutrients on productivity, energitics and economics of rice. Oryza 45(2), 166-168.

Mahajan, G., Bharaj, T.S., 2008. Yield and water productivity of rice cultivars as influenced by transplanting dates and seedling age in irrigated semi-arid subtropical environment.Asian and Australasian Journal of Plant Science and Biotechnology 2, 15-19.

Masud, M.M., Abdullah, M., Zahan, A., Nayeem, A.M., Abdul, J.M., 2014. Effect of planting methods on the yield and yield Attributes of Short Duration Amman Rice. American Journal of Plant Sciences 5, 251-255. 
Nuttonson, M.Y., 1948. Some preliminary observation of phonological data as a tool in the study of photoperiod and thermal requirement of various plant material. In: proceeding of a symposium on vernalization and photoperiodism (Murneek, A.E., Whyte, P.R. (Eds.)). Chronica Botanica publishing co. Walthani, M.A., U.S.A.

Nandan, R., Singh, V., Singh, S.S., Kumar, V., Hazra, K.K., Nath, C.P., Poonia, S.P., Malik, R.K., 2018.Comparative assessment of the relative proportion of weed morphology, diversity, and growth under new generation tillage and crop establishment techniques in rice-based cropping systems. Crop Protection 111, 23-32.

Pawar, S.B., Mahadkar, U.V., , Jagtap, D.N., Jadhav, M.S., 2017. Effect of different planting techniques and inputs on yield attributes and yield of rice (Oryza sativa L.) during kharif season. Farming and Management 2(1), 16-21.

Pal, R., Mahajan, G., Sardana, V., Chauhan, B.S., 2017. Impact of sowing date on yield, dry matter and nitrogen accumulation, and nitrogen translocation in dryseeded rice in North-West India. Field Crops Research 206, 138-148.

Raj, S.K., Mathew, R., Jose, N., Leenakumary, S., 2012. Enhancing the productivity and profitability in rice cultivation by planting methods. Madras Agricultural Journal 99(10-12), 759-761.

Rajiv, S.K., 2013. Response of basmati (Oryza sativa L.) rice varieties to system of rice intensification (SRI) and conventional methods of rice cultivation. Annals of Agricultural Research 34(1), 50-56.
Sharif, A., Elizabeth, H., Muhammad, S., Bhagirath and Chauhan, S., 2014. Optimizing sowing management for short duration dry seeded aman rice on the High Ganges River Floodplain of Bangladesh. Field Crops Research 169, 77-88.

Singh, N., 2013. Root growth, yield and NPK uptake of rice (Oryza sativa L.) varieties grown by system of rice intensification with varying planting geometry and weed management practices. Annals of Agricultural Research New Series 34(1), 26-35.

Singh, G., Narwal, S.S., Rao, V.U.M., Dhaiya, D.S., 1990. Effect of sowing date on requirement of growing degree days, heliothermal units and photothermal units on phenology of winter maize (Zea mays). Indian Journal of Agricultural Sciences 60(11), 723-731.

Singh, H., Buttar, G.S., Brar, A.S., Deol, J.S., 2017. Crop establishment methods and irrigation schedule effect on water productivity, quality, economics and energetic of aerobic direct-seeded rice (Oryza sativa L.). Paddy Water Environ 15, 101-109.

Singh, S.P. Sreedevi, B., Kumar, R.M., Subbaiah, S.V., 2008. Grain yield and economics of wet direct sown rice under different establishment methods and nitrogen schedules.Oryza 45(3), 245-246.

Yadav, L., Meena, R.N., 2014. Performance of aromatic rice genotypes as influenced by integrated nitrogen management. Indian Journal of Agronomy 59(2), 251-255. 